\title{
Discussion to the paper by Ralph Wright
}

\author{
Chairman: Dr Geoffrey Watkinson
}

Chairman. Was the frequency of this antibody in ulcerative colitis more common in patients who had systemic complications?

WRIGHT. No, no correlation at all.

Chairman. Disappointing.

WRIGHT. Yes it is.

MCCONNELL. Does the titre of mitochondral antibody vary with treatment? In other words, if you put the biliary cirrhotic on to steroids, does this change the titre?

WRIGHT. I don't know. But certainly some of the titres of the antinuclear factor vary with treatment. We have no personal experience of this.

QUESTION. It is interesting that a bacterial antigen to the intestinal flora has been suggested again in ulcerative colitis as was suggested 2 or 3 years ago.

WRIGHT. No further work has been done. The other attempts along these lines have been to study the lymphocytes of patients with ulcerative colitis which have been stimulated with various antigens, including colonic and bacterial antigens. When transformation of lymphocytes occurs in response to antigens this has been taken as an index of delayed hypersensitivity.

QUESTION. Is there any direct experimental evidence to show that these antibodies as opposed to lymphocytes actually produce lethal or damaging effects to the cells on which they become attached?

Wright. I think that the only possible evidence is in relation to thyroid where it has been shown that if the cells are close enough to burst in tissue culture then the circulation of the thyroid antibody inside the cytoplasmic antibody will kill the cell, one has to know how to handle the cell first. The suggestion is that these cellular antibodies might react synergistically with the intestinal cells. Again it might well be that we have identified the wrong type of antibody.

This may well be so, because we are looking at antibodies which are reacting with cell cytoplasm and nuclei. We are not looking at antibodies which are reacting on the cell surface. And if these antibodies are going to cause cell destruction this might mean that we'll have to examine the cell surface, but we just haven't got the technique which enables us to do this.

\section{Acknowledgments}

The Council of the Fellowship of Postgraduate Medicine gratefully acknowledge the help of the following in the production of these two issues on 'Postgraduate Gastroenterology':

Berk Pharmaceuticals Limited Boehringer Ingelheim Limited Glaxo Laboratories Limited Parke, Davis and Company Sandoz Products Limited G. D. Searle and Company John Wyeth and Brothers Limited Pfizer Limited 